\title{
On Methods to Improve College English Teaching under the Background of Socialization of NMET
}

\author{
Junling Yan \\ School of Foreign Languages, Chifeng University, Chifeng, Inner Mongolia, China \\ 13947659118@126.com
}

Key words: Socialization of NMET; The current situations of college english teaching; Methods to improve

\begin{abstract}
With the help of the great reform of socialization of college entrance examination English, college English teaching must also make the corresponding reform measures so as to form a comprehensive range of an overhaul. In order to reform and improve college English teaching, we must understand contents relating to socialization of the college entrance examination English and understand the current situations of college English teaching and put forward improved methods of college English teaching. This not only conforms to the tide of the reform of socialization of college entrance examination English, but also greatly improves the quality of college English teaching.
\end{abstract}

\section{Introduction}

The development of socialization of the college entrance examination English is contemporary demand of the market[1]. Our college English talents do not lack now, but in the society there is such a phenomenon: on the one hand, English major graduates can't find a job; on the other hand, there are many enterprises and institutions which can't find English talents whom they need. This shows that English talents are not adapted to the demand of the market. The development of the socialization of the college entrance examination English can scout for English talents' potential ability and avoid students in colleges and universities who do not agree with their own potential. College English teaching doesn't show special skill has emerged as a director of the phenomenon. In order to solve this problem, we must understand socialization of the college entrance examination English and the current situations of college English teaching so as to put forward improvement methods[2].

\section{Socialization of NMET}

As the reform of socialization of NMET, English is becoming especially prominent instead of being weakened. English as a kind of important tool to communicate with the outside world, there is little doubt that if NMET cancels English, it will be what kind of situation? You can imagine! In the future of the reform of English, NMET only changes English examination forms. NMET in the future will no longer be the final, but during a year students can take more than an exam and get the optimal results to participate in the final results. In the common examinations in a senior high school, students can continuously refresh their grades by learning. Such reforms, to a certain extent, improve students' learning efficiency. Students will not wait to assault learning when the exam draws near. Such reforms can help students lay a solid foundation for their college English study. At the same time, such reforms can improve students' English ability as a whole[3].

The reform of socialization of the college entrance examination English has its own advantages. First of all, students sort out learning goals in different stages. In this way, it makes them learn active learning and it changes teachers' cramming teaching models. It helps to develop students' individual characters and make learning present the situation of hundreds of flowers. Secondly, such reforms are to make education institutions become to select all kinds of talents' agencies rather than fixed and invariable inspection agencies. This also makes tests more and more flexible. At the same time, it can also let students all show. Moreover, this method can also change the gap between good schools and bad schools, but form a difference between various professionals. When a student looks 
for a job, employing units won't directly refuse job seekers because they do not come from a good university and eliminate their opportunities to show their abilities. It also contributes to the development of the social talent equilibrium. Finally, the reform of socialization of college entrance examination English opens the door for the development of social diversity in the future. In such an examination system, students can give full play to their talents and play their innovative potentials[4]. This reform lays the foundation for students' future development and makes students out of the predicament of exam-oriented education. The socialization of the college entrance examination English is the developing direction of English. This also prompts the development direction of college English teaching to make the corresponding adjustment. In order to help college English teaching to make the corresponding adjustment, first understand the current situations of college English teaching and suit the remedy to the case.

\section{The Current Situations of College English Teaching}

English teaching modes are simple. College English teaching is still limited in high school English teaching methods. It is mostly an inherent pattern about a lecturer. It can't mobilize students' initiative. It can't stimulate students' interest in learning in the classroom. It can't fully make classroom atmosphere active. With the rapid development of modern science and technology, teaching equipment constantly updates and application of multimedia technology makes learning more convenient[5]. At the same time, in the process of English teaching, teachers excessively depend on these high-tech things, but can't take full advantage of their advance. Teachers just treat them as teaching tools and don't provide students with a better learning platform. It is because of improper use of these devices that cause the deficiency of teaching methods. For example, in many colleges and universities, English teachers don't personally teach students knowledge and don't explain those difficult words or sentences in order to save trouble. They only do PPT to show knowledge. Contents on the PPT are enough. There is the focus of the outstanding, but students understand less and just mechanically take notes, which makes students sufficient understanding of knowledge. Some new knowledge needs a teacher to explain. If teachers just rely on PPT, students can't understand[6].

Students' English learning autonomy is not strong. Don't preview before class and don't review after class so that students do not understand contents which a teacher says. In class, if English teachers lecture in English or speak too fast, causing students to be confused about what a teacher says like listening to a sealed book[7]. Learning autonomy is not strong and sometimes students concentrate in class so that they don't know where teachers go. Students' English learning autonomy is not strong and we can see it from following aspects, such as, they don't remember English words; they don't remember English expressions; they don't remember English idiomatic usage and so on. How do we talk about teaching quality?

Students' English foundation is weak. Some students' English foundation is extremely weak. In college English teaching, teachers lecture in English as far as possible in order to improve students' ability. It is not difficult for good students to understand teachers, but there are a part of students with bad foundation who can not master enough knowledge and can not understand teaching contents and even can't keep pace with teachers. Teachers lecture, for example, that they will use connected speech[8]. Here are some examples which students are very difficult to understand.

\begin{tabular}{|l|l|}
\hline Categories & Examples \\
\hline Consonant +vowel & Please pick it up. \\
\hline R/Re +vowel & I looked for it here and there. \\
\hline Consonant + semivowel & Would you like a cup of tea? \\
\hline Vowel + vowel & The question is too easy for him to answer. \\
\hline Plosion + plosion & $\begin{array}{l}\text { The big bus from the factory is full of } \\
\text { people. }\end{array}$ \\
\hline Plosion + rub & I went there alone at nine last night. \\
\hline
\end{tabular}


English teaching evaluation ways and methods are to be perfect. Now most college English assessment methods are public CET-4, CET-6, professional Level 4 and professional Level 8. It was set to test students' English ability at the first time. However, there have been some deviations in the process of running. Now public CET-4, CET-6, professional Level 4 and professional Level 8 are a big problem to students. In order to be able to pass an exam, students go back to exam-oriented education which is like in junior high schools. Blindly to remember English words, to recite English composition and to pay no attention to the improvement of English ability finally will only cause the following phenomena: students can not realize actual application; students can't speak students can't read; even Chinese-style English grammar appears. Chinese English grammar contents and actual English are exactly opposite. What's more, in order to pass public CET-4, CET-6, professional Level 4 and professional Level 8, some students do not hesitate to spend money on some high-tech equipment to get answers and some students even use money to buy answers directly[9]. Thus, whether universities can demand students through public CET-4, CET-6, professional Level 4 and professional Level 8 or not also has shortcomings and also needs to be perfect.

\section{Methods to Improve College English Teaching}

Teachers should improve English teaching methods. In English teaching in colleges and universities, teachers should change traditional original patterns and study that sort of open teaching mode. Students are dominant and teachers are complementary. More communication happens between students so that students can adapt to language expression differences between different people and also can learn from different people and also can exercise their own spoken language abilities and also can improve their own learning methods. Students can share different points of view, take each other's opinions and learn from other strong points to offset their weakness. In English teaching, teachers should pay attention to listening, speaking, reading and writing. Teachers should cultivate students' English thinking. Teachers should let students be familiar with English language habits. Thus, teachers can really improve students' English ability and promote their learning of English knowledge. In addition, teachers should make good use of some equipment for high-tech, provide more new materials for students and share some latest extracurricular knowledge with students so as to let students learn more foreign knowledge and know more about English learning. At the same time, we can also use such movies, magazines and English songs to improve students' English abilities. See some good foreign films, such as, The Godfather, The Shawshank Redemption and so on. There are some foreign English and Chinese reference books, such as, Harry Potter, The Thorn Birds, Jane Eyre and so on. In teaching, teachers can choose free time to play films to students, or recommend films to students who can watch them after class. As for books, students can arrange time freely. On the one hand, let students learn English knowledge. On the other hand, increase interest in learning English[10].

Teachers should teach students according to their aptitudes. College students are from all over the country. Each student's situation is different as there are not completely same two leaves in the world, so their basic English and their abilities are different. In reaction to the phenomenon, teachers will have a set of suitable teaching schemes for different level students. Teaching plan formulation depends on students' basic English and their abilities, for example, early in the spring and autumn period and the warring states period, there was a story about $\mathrm{Zi} \mathrm{Lu}$ and $\mathrm{Ran}$ You. $\mathrm{Zi} \mathrm{Lu}$ and Ran You asked Confucius the same question, however, Confucius's answers were opposite. Confucius was against Zi Lu's answer and was for Ran You's answer because Zi Lu liked competition and Ran You was more coward. According to their aptitudes, Confucius gave different opinions according to their different characters. Suppress $\mathrm{Zi} \mathrm{Lu}$ and encourage Ran You. This is according to their aptitudes. Teachers should also learn from the great educator Confucius. Of course, teachers can't make a plan for every student. Teachers should classify students. For this kind of students, teachers should be how to teach them. For that kind of students, teachers should be how to teach them. Just as different students majoring in English choose different study directions, they can choose the direction of normal English, the direction of English translation and the direction of 
English literature. This multidirectional choice can give students space where students can play to their hobbies and potentials. At the same time, teachers should use competition means to improve students' English ability and stimulate students' interest in learning English.

Teachers should help students build up confidence. Now in most colleges and universities, students' learning enthusiasm is not high and learning attitude is not correct. The causes of this phenomenon are: Firstly, students thoroughly relax after a heavy university entrance exam. Secondly, students' foundation is weak. They feel they can't learn or learn well, so learning and non-learning are all the same. When they learn, their accomplishments aren't improved. Thus, they lose confidence in learning. Thirdly, students for their future goals are not clear and they can't master enough English knowledge, so it is difficult for them to learn English. In view of above three points, teachers should help students build up confidence. Teachers require students to set up short-term English learning goals, for instance, within a week, they learn how many English words and understand how much English grammar knowledge. When a week ends, teachers should let students see their own progress, see learning achievements, know worthy efforts, making them psychologically have confidence in themselves and changing their former ideas that they can't learn. Teachers can also use some inspirational examples to encourage students to study, telling them weak foundation which has nothing to do with themselves. They can take their time. Like Edison, he could continue to study out of failure of countless times until success.

By understanding socialization of the college entrance examination English and college English teaching, put forward some improving methods of college English teaching. Hope these methods can implement into college English teaching. Only in this way can improve college English teaching. Only improving college English teaching can realize the socialization reform of college entrance examination English.

\section{References}

[1] Li Chengwei. Pros and Cons about NMET Socialization [J]. Journal of Exam Weekly, 2014 (10) : 4

[2] Li Tao. The Socialization of the College Entrance Examination Study [J]. Modern Education Science, $2013(2): 5-10$

[3] Zheng Caiyun and Chen Shugen. Socialization of the College Entrance Examination Question Analysis [J]. Journal of Beijing Industrial Vocational and Technical College, (2009)(7) : 143-146

[4] Han Huiqing. College English Teaching Reform Ideas [J]. Journal of Luoyang Normal College, 2003 (3) : 113-115

[5] He Qixin, Yin Tongsheng, etc. Several Opinions on Reform of the Foreign Language Professional Undergraduate Course Education [J]. Foreign Language Teaching and Research, 1999 (1) : 24-28

[6] Jia Guodong. Multimedia Teaching to Promote New Ways of College English Teaching [J]. Foreign Language World, 1999 (2) : 30-35

[7] Ministry of Education. English Course Teaching [M]. Shanghai Foreign Language Education Press,(2007).

[8] Ministry of Education. Teaching Requirements for College English Courses [M]. Shanghai Foreign Language Education Press,(2007).

[9] Cheng Xiaotang. Examination is not the natural enemies of the new curriculum - on the new curriculum under the background of the relationship between teaching and evaluation thinking [J]. People's Education,( 2007).

[10] Dai Weidong, Huang Ren. Changing Ideas, Comprehensively Promote the Reform of Foreign Language Teaching [J]. Journal of International Studies, 1997 (6) : 1-4 